\title{
Acehnese Cultural Leaders' Perspective on Anemia in Pregnant Women: A Qualitative Study
}

\author{
Darmawati Darmawati $\mathbb{D}^{1,2}$ Tongku N. Siregar $\mathbb{D}^{1,}{ }^{3}$ Hajjul Kamil, ${ }^{4}$ and Teuku Tahlil ${ }^{5}$ \\ ${ }^{1}$ Graduate School of Mathematics and Applied Science, Universitas Syiah Kuala, Aceh 23111, Indonesia \\ ${ }^{2}$ Department of Maternity Nursing, Faculty of Nursing, Universitas Syiah Kuala, Aceh 23111, Indonesia \\ ${ }^{3}$ Faculty of Veterinary, Universitas Syiah Kuala, Aceh 23111, Indonesia \\ ${ }^{4}$ Department of Management Nursing, Faculty of Nursing, Universitas Syiah Kuala, Aceh 23111, Indonesia \\ ${ }^{5}$ Department of Community Nursing, Faculty of Nursing, Universitas Syiah Kuala, Aceh 23111, Indonesia \\ Correspondence should be addressed to Darmawati Darmawati; darmawati.fkep@unsyiah.ac.id
}

Received 3 March 2020; Accepted 12 May 2020; Published 9 June 2020

Academic Editor: Carol J. Burns

Copyright ( 2020 Darmawati Darmawati et al. This is an open access article distributed under the Creative Commons Attribution License, which permits unrestricted use, distribution, and reproduction in any medium, provided the original work is properly cited.

\begin{abstract}
Introduction. Anemia during pregnancy is one of the commonest issues in pregnancy. Cultural belief is among the contributing factors to this problem. This study aims to explore the cultural leaders' perception on Acehnese culture regarding anemia in pregnancy. Methods. The qualitative study was conducted using three in-depth interviews and a focus group discussion with Acehnese cultural leaders. Data analysis was conducted by the inductive content analysis method. Results. Four themes emerged from interviews and discussion: (1) cultural beliefs about anemia; (2) locally resourced food; (3) husband participation in preventing anemia during pregnancy; (4) do's and don'ts. Conclusion. Our findings provide insight into how cultural leaders' perceptions of anemia are in pregnancy and how they are integrated strongly into Acehnese people's lives. These findings would assist in developing culturally adapted strategic policy to prevent anemia during pregnancy.
\end{abstract}

\section{Introduction}

Pregnancy is a critical phase in a woman's life and has a great impact on their daily lives [1]. Sometimes, this phase can cause fear of death if pregnancy is not well prepared, so various complications will arise during pregnancy [2]. One of the commonest pregnancy problems especially in developing countries is anemia, where the hemoglobin levels are less than $11 \mathrm{gr} / \mathrm{dl}$, affecting the oxygen-carrying capacity of red blood cells to body tissues [2, 3].

According to the World Health Organization, the incidence of anemia among pregnant women continues to increase. More than 30 million (38.2\%) pregnant women experience anemia worldwide. This number is predicted to increase significantly in the future [4]. It is also estimated that more than $38.2 \%$ pregnant women suffered with anemia around the world, and this condition is the main cause of maternal death [5]. A study in Indonesia found that the prevalence of anemia in pregnant women in this country was $48.9 \%$ [6]. Furthermore, anemia during pregnancy has a negative maternal and child effect and increases the risk of maternal and perinatal mortality. The negative effects for the mother include fatigue, difficulty of doing daily activity, increased risk of heart disease, and death [7]. Anemia can cause premature birth and low birth weight, and fetal weight does not correspond to the gestational age [2].

Anemia is a problem caused by a disruption in meeting the nutritional needs of the mother and the fetus. One of the factors that can affect this condition is the existence of cultural beliefs to follow a recommendation from the cultural leaders. The dietary adjustment of pregnant women is influenced by various reasons coming from various sources [8]. Some of the pregnant women seek the information from health workers which can be scientifically rationalized [9]. However, there are also women who get information about pregnancy from cultural or religious sources [8]. Cultural 
value plays a big role in regulating the life in various phases, especially during pregnancy, where people really consider pregnancy as a special event, where many rituals must be performed [10].

Acehnese is one of the ethnic groups that still adheres to cultural beliefs, located in the Sumatra Island and dubbed by "seuramoe makkah" because it is dominated by Islamic teachings [8]. The values that are believed in Aceh are also called Reusam, which is the norms that have been followed for generations and have undergone changes and unwritten [11]. However, the majority of Acehnese cultural values is oriented from Islamic values, "adat ngon hukom (syariat), lagee ngon sifeuet, hanjeuet cre bre." It means that there are two inseparable unions between Islamic values and traditional customs in the life of the Acehnese people [12, 13].

In Acehnese culture, there are cultural leaders who master all the traditional values. Usually, the values of life are conveyed by traditional leaders through poetry or narit/ hadis maja to make the message to be more easily memorized and applied in daily life [13]. Narit madja is the third level of truth in the Acehnese people's life after the revelation of Allah SWT and the hadith of Prophet Muhammad. The message or cultural values consisted of the words from older people that can be used as advice, guidance, and prohibitions, especially for special groups such as pregnant women [12]. Due to the strong position of narit madja, all of the health messages related to pregnancy are effectively implemented by the society if they are integrated with narit maja. This study aims to explore the perceptions and views of cultural leaders regarding pregnancy, especially in relation to anemia. It is a hope that this value can be juxtaposed with things that need to be carried out medically by pregnant women during pregnancy.

\section{Materials and Methods}

2.1. Study Design and Participants. This qualitative study involved data collection using focus group discussion (FGD) approach and in-depth interviews (IDIs) conducted to explore the cultural leaders' perceptions about Acehnese culture regarding anemia in pregnant women in Aceh Besar District, Aceh, Indonesia. The participants recruitment was carried out using a convenience sampling technique to participate in in-depth interviews; there were 3 cultural leaders who participated in this process. Next, a purposive sampling technique was used to select participants for FGD, and we randomly selected 9 cultural leaders. Participants included cultural leaders who were members of the Acehnese Cultural Council and had experience as cultural leaders for more than 20 years. This study was approved by the Ethics Committee of the Nursing Faculty, Universitas Syiah Kuala, Aceh (code no. 1130041111218).

2.2. Data Collection and Analysis. In-depth interviews were conducted using open-ended questions. These interview tools were translated into the Acehnese language (the language spoken by the participants). The main themes discussed include cultural beliefs about anemia, the role of cultural leaders, and some poetry or narit maja that guide the Acehnese women in their pregnancy, especially to prevent anemia.

During the process, the head of the Acehnese Cultural Council was informed about the purpose of the study before the data collection was done. The head of the Acehnese Cultural Council contacted the cultural leaders in the Aceh Besar district to participate in the study. Then, the head of the Acehnese Cultural Council identified three cultural leaders who have more experience to take an in-depth interview. After informed consent, the interview and discussion were done according to the guidelines. The questions were arranged from general to specific. The FGD lasted between 100 and 120 minutes, and IDIs lasted between 60 and 70 minutes for each session. All the information and discussions were recorded by digital voice recorders and noted by hand. The total number of participants in FGD was 9 cultural leaders.

The inductive content analysis (ICA) method was used to evaluate, encode, and analyze the results of verbal interviews. The results of interviews and discussions were listened several times before copied in Acehnese and translated into the Indonesian language. This translation process has involved language experts from language institutions. After that, the results of the transcript are read several times to get a good contextualized understanding. Furthermore, a list of categories and subthemes is developed based on research objectives to answer the whole research questions [14]. Another investigator independently reviewed and verified these categories and subthemes.

\section{Results}

In this study, a majority of FGD participants were 40-60 years old, 55, and 6\% of them held a bachelor's certificate. More than half of the participants had experiences as cultural leaders for 11-20 years. In addition, as many as 3 participants as key informants in in-depth interviews were members of the Acehnese Cultural Council who had experience as cultural leaders for more than 20 years. The codes were classified into themes, categories, and subcategories. In the process of analyzing qualitative data after categorizing the code and removing the same code, 9 codes were obtained in 9 subcategories, 7 categories, and 4 main themes, which were: cultural beliefs about anemia; locally resourced food; husband participation in preventing anemia during pregnancy; and do's and don'ts (Table 1).

3.1. Cultural Belief about Anemia. The pregnant women in this study revealed that anemia in pregnant women is caused due to inadequate intake of nutritious food.

"It means that anemia occurs if pregnant women do not consume good food for their pregnancy, for example foods that contain nutrients" (P1).

Almost all of the participants also said pregnant women will experience physical changes and eventually lose their 
TABLE 1: Major findings with the code, subcategories, categories, and themes.

\begin{tabular}{|c|c|c|c|}
\hline Code & Subcategory & Category & Theme \\
\hline $\begin{array}{l}\text { Inadequate intake of nutritious } \\
\text { food caused anemia }\end{array}$ & Anemia is caused by food & $\begin{array}{c}\text { Traditional leaders' perception about } \\
\text { pregnancy changes and anemia } \\
\text { symptoms }\end{array}$ & Cultural belief about anemia \\
\hline $\begin{array}{l}\text { The condition of the body } \\
\text { changes during pregnancy }\end{array}$ & $\begin{array}{l}\text { Changes in physical health } \\
\text { and appetite during } \\
\text { pregnancy }\end{array}$ & & \\
\hline $\begin{array}{l}\text { Dizziness, nausea, and } \\
\text { vomiting often occur during } \\
\text { pregnancy }\end{array}$ & $\begin{array}{l}\text { Anemia always happens in } \\
\text { every pregnancy }\end{array}$ & & \\
\hline $\begin{array}{l}\text { Bean sprouts, tofu, and } \\
\text { fermented soybean are } \\
\text { nutritious food }\end{array}$ & $\begin{array}{l}\text { Types of beans that pregnant } \\
\text { women should consume }\end{array}$ & Nutrition food & Locally resourced food \\
\hline Janeng contains iron & $\begin{array}{l}\text { Tubers that are rarely } \\
\text { consumed and contain iron }\end{array}$ & Neglected available resources & \\
\hline $\begin{array}{l}\text { Husband's support in seeking } \\
\text { therapy and religious support }\end{array}$ & Religious advice & Suggested religious behavior & $\begin{array}{l}\text { Husband participation in } \\
\text { preventing anemia during } \\
\text { pregnancy }\end{array}$ \\
\hline $\begin{array}{l}\text { Husband recites the Holy } \\
\text { Qur'an }\end{array}$ & Religious husband's role & $\begin{array}{l}\text { Bonding with God determines the } \\
\text { mother and baby condition }\end{array}$ & \\
\hline $\begin{array}{l}\text { Hadis maja that supports } \\
\text { nutrition food during } \\
\text { pregnancy }\end{array}$ & Acehnese culture & Culture-based advices & Do's and don'ts \\
\hline Listens hadis maja & Poetry advice & $\begin{array}{c}\text { Lower their gaze to unnecessary } \\
\text { images/views }\end{array}$ & \\
\hline
\end{tabular}

appetite. This condition causes pregnant women not to consume food, preventing the pregnant women to meet their nutritional needs.

Talking about physical symptoms, the majority of cultural leaders knows the symptoms that always appear related to anemia in pregnancy which are dizziness, nausea, and vomiting. Some of them mentioned

"So, in the early pregnancy, pregnant mothers often feel dizzy. When the health worker checked it up, it is because of lacking blood (anemia). It will be happen, always happen during pregnancy" (P7)

An Acehnese poem also conveyed this to Acehnese people. The content of the poem was

"Dizziness, headaches, and always weak, it is the signs of lack of blood and must be paid with attention. Why does it matter? Because of consuming less nutritious foods."

3.2. Locally Resourced Food. The majority of the participants stated that, in culture of Aceh, pregnant women are encouraged to consume nutritious food. Pregnant women were always encouraged to meet their nutritional needs through food consumption, especially food that contain iron. Some of them recommend pregnant women to consume bean sprouts:

"I told them to eat bean sprouts and green beans. I said to them: For those of you (who have anemia), this is the cure. Eat bean sprouts and green beans" (P5)
Besides bean sprouts, cultural leaders also advise pregnant women to consume processed soybean food products. They believe this food is a source of nutrients, especially iron.

"Pregnant people should eat well. Especially if you have less blood (anemia), you have to eat a lot of iron, like in tempe (fermented soybean) and tofu that has a lot of iron" (P8)

In particular, a message in an Acehnese poem suggests pregnant women to meet the body's nutritional needs in order to prevent anemia. The content of the poem is:

In addition to these food which are often found in the traditional market, cultural leaders also recommend pregnant women to consume janeng, a type of tubers that is widely available in forests that is now rarely consumed by the Acehnese people.

"We have forgotten, actually there is janeng. It has a large shape, found in the forest. It is beneficial for increasing iron, reduce uric acid levels, cholesterol and glucose. It can be anticipated with janeng." (P9)

3.3. Husband Participation in Preventing Anemia during Pregnancy. The majority of cultural leaders mentioned that they highly recommended the husband to support their wife's pregnancy and become a good partner. One thing that they can do is to help the wife in obeying medical advice given by health workers, and the most important thing is to pray to God for the pregnancy process.

"Someone came with her husband, I made a water that I had read prayers on and a short letter in the Qur'an. 
Thanks to God, after drinking the water, the condition of her body was not weak and looked healthier. But I told her husband to still have to pray to God and provide nutritious foods and do not forget to keep on taking iron supplement" (P4)

As an area that upholds religiosity, almost all aspects of Acehnese culture contain religious elements, including in pregnancy. The majority of participants also said that they encouraged the husbands to be carrying out religious commands, such as reading the Qur'an to provide psychological calm to their wives. One of them said

"In Al-Qur'an, there are many verses to anticipate from various disturbances so that mothers and babies are healthy. They can read Surah An-Nazi' at and Al-Insyirah. In addition, it must also be an effort, endeavor that God will protect the wife's womb and still be able to carry on activities as usual" (P7)

An Acehnese poem said that it is important for the husband to support his wife and help meeting the needs of pregnant women. The content of the poem was

"It is a very good time, reminded by the father to the mother, when going to bed at night, it is the best time to taking iron".

In the end, the poem also advised that pregnant women should continue to pray to God and ask for a good process of pregnancy. The content of the poem was as follows:

"What I say it must be obeyed, pregnant women also pray to God so the children and mothers always healthy."

3.4. Do's and Don'ts. Related to the Acehnese culture, there are many things that must be done and should be avoided by pregnant women. A pregnant woman should listen to the cultural advices that are said by parents, especially by cultural leaders. This suggestion can be found in the hadis maja, which is the poem that contains a positive message to be carried out in daily life, including during pregnancy. It was intended so that pregnant women can listen to good things and keep away from activities that are not useful, such as watching drama or television.

"So, it is better for pregnant women to reduce watching dramas that are unuseful. If the mother is often dizzy, weak, and not excited, they should not watch television, but listen to the good cultural poetry (hadis maja) and it could be useful for the development of her baby" (P8)

Some examples of hadis maja which contain good recommendations for pregnancy are

"Choose vegetables with green leafs and consume shrimp. Especially if it's planted in your own garden."
"After that, spinach leaves with shrimp, chicken with janeng. And also chicken eggs are perfect, so there is a desire to eat iron."

\section{Discussion}

This present study showed that Acehnese cultural leaders had positive perceptions about behavior in preventing anemia during pregnancy which is in line with the expectations of the health workers. Acehnese cultural values also believed that the cause of anemia was due to the inadequate nutrients consumed by the pregnant women. This perception is supported by another study conducted by Kassebaum et al. [15] who found that $50 \%$ of anemia in pregnancy were caused by inadequate intake of nutrients, especially iron. The increased need for iron is caused by the expansion of maternal red blood cell mass to facilitate oxygen transfer to the fetus so it can grow and develop properly [16]. Increasing intake of varied and healthy food along with additional iron supplements can prevent depletion of iron reserves in the body [17]. In the end, positive understanding of the cultural leaders that anemia can be caused by poor nutrition intake is an important basic understanding for them in educating pregnant women.

Moreover, the cultural leaders perceived that anemia pregnant women always have clinical symptoms such as dizziness, nausea, and vomiting that last continuously and believed that this condition is normal during pregnancy. Basically, this perception is not only owned by cultural leaders but also by the majority of pregnant women. This is consistent with the results of the study conducted by Chatterjee and Fernandes who found that Indian pregnant women perceived that anemia was normal during pregnancy because most of the pregnant women had suffered from this condition [18]. Cultural leaders, as people who are trusted by their words by pregnant women, should understand the pathological conditions during pregnancy especially anemia, so they can provide useful information for pregnant women. The pregnant women's belief towards cultural leaders and the traditional values does not apply only to the Acehnese people. A study conducted in Northern Tanzania also found that Maasai pregnant women preferred the traditional way of carrying their pregnancy [19].

Based on the study result, we agree with the cultural leaders that pregnant women should prioritize daily food intake and iron tablets to meet the needs of essential substances such as iron. This statement is also accompanied by some poetry from the Acehnese poetry called hadis maja which supports pregnant women in consuming nutritious food. Hadis maja is very well known in the lives of the Acehnese people and strongly believed by the Acehnese people. So, it is a very good strategy to integrate in the antenatal services. Today, the expressions of narit maja can be read through Acehnese cultural books. Every single thing and aspect in the life of Acehnese people has been explained in the narit maja [12].

One of Acehnese traditional food ingredients that is easily obtained and always delivered by traditional leaders to pregnant women is green beans. Green beans are legume 
products that contain a lot of iron. A study conducted by Zakaria et al. found that there was a significant effect on the increase in hemoglobin levels by giving green bean juice (Phaseolus radiatus) [20]. Pregnant women are also encouraged by the Indonesian Ministry of Health to consume 90 tablets of iron during pregnancy [21]. A previous literature study conducted by Yakoob and Bhutta [22] found that daily supplementation containing iron has a percentage of $67 \%$ that can reduce the incidence of iron deficiency anemia.

In addition to the food mentioned above, there are local food ingredients which unfortunately have begun to be abandoned by the Acehnese people. Cultural leaders said that janeng are tubers which contain a lot of iron. Janeng (Dioscorea hispida) is used as a food source in several tropical countries [23]. It is the basic knowledge that strengthens traditional leaders to deliver health information that is useful for pregnant women, such as local food rich in nutrients, especially iron.

Pregnancy carried out by a woman should be followed by giving full support by her husband. Acehnese cultural leaders always encourage husbands to provide support through religious aspects. This support is one step that can be taken by the husband and includes the type of emotional support. The direct support from the husband can provide individual confidence and increase feelings of self-esteem, motivation, coping, and morals [24]. The supports of the husband will make the mother feel cared for and being motivated to take care and maintain her pregnancy as well [25]. Faith in prayer can be a strength that should also be accompanied by effort (ikhtiar) as stated in the QS Ar Ra'd: 11 that means "Indeed, Allah will not change the condition of a people until they change what is in themselves. And when Allah intends for a people ill, there is no repelling it. And there is not for them besides Him any patron." Acehnese cultural leaders believe that pregnancy is an event that cannot be separated from religious beliefs, so they expect the husband can meet these needs. Religious needs during pregnancy are also seen in Urban Accra, Ghana. They believe that all pathological symptoms during pregnancy are a result of God's curse because they rarely worship [26].

Overall, this study found important information about cultural leaders' perceptions about Acehnese culture related to anemia in pregnancy. Previously, there were minimal research studies that examined the perceptions of cultural leaders related to pregnancy especially anemia. The results of this study can be used as a supporting reference for health workers in providing health information and counseling to pregnant women. However, there are some limitations in this study, for instance, additional FGDs with other cultural leaders would enrich the data. In addition, more representative cultural leaders from other regions in the country would also help to explore the issue and approach to minimize the anemia prevalence in pregnancy.

Positive cultural beliefs conveyed by cultural leaders to pregnant women can be a good input to be conveyed at antenatal counseling sessions in the public health centers. Development of the counseling intervention program that incorporates Acehnese cultural recommendations can be applied in the implementation of antenatal services.
Counseling interventions involving local culture will make it easier for counselors to make pregnant women trust and follow pregnancy-related advice given by counselors. These study findings would assist in the development of new antenatal counseling models that integrate local cultural values as conveyed by cultural leaders. These can potentially inform government policies specifically in the domain of maternal and child health to improve the quality of antenatal counseling to decrease anemia prevalence in pregnancy.

\section{Conclusion}

This research described Acehnese cultural leaders' perception about cultural views related to anemia in pregnancy. It is found that several important aspects are to be underlined. The first aspect is cultural leaders believed that anemia is caused by food consumed, and it makes various accompanying symptoms. Anemia in pregnancy can be prevented by consuming nutritious food. There are several tubers that have been forgotten by the Acehnese people even though they have great benefits, including janeng. From the cultural standpoint, the husband plays a bid role in supporting pregnant women, especially by maximizing emotional support with a religious approach. In the end, cultural leaders also advised that pregnant women should heed the cultural values contained in the Acehnese poetry (narit maja).

\section{Data Availability}

The data used to support the findings of this study are available from the corresponding author upon request.

\section{Conflicts of Interest}

The authors declare that there are no conflicts of interest regarding the publication of this paper.

\section{Authors' Contributions}

The main author (DD) is the person who conducted the research and wrote the principal draft of the manuscript. $\mathrm{NT}, \mathrm{KH}$, and TT are the team that corrected each writing, directed the design of the study, supervised the research conducted, and revised the text. All authors have also read and approved the manuscript.

\section{Acknowledgments}

The authors would like to acknowledge the cultural leaders in the Acehnese Cultural Council who were willing to participate and share their perceptions in this study. The authors also thank Elly Wardani and Widyawati for assistance in question design and data triangulation as well as Masyithah Audina, Khiyurul, and Nia Saumania for their contribution. 


\section{References}

[1] K. Baharzadeh, T. Marashi, A. Saki, A. Z. Javid, and M. Araban, "Using of health belief model to promote preventive behaviors against iron deficiency anemia among pregnant women," Journal of Research \& Health, vol. 7, pp. 754-762, 2017.

[2] K. B. Daka and D. D. B. Jayanthigopal, "Assessment of knowledge and practice towards prevention of anemia among pregnant women attending antenatal care at government hospitals in west assessment of knowledge and practice towards prevention of anemia among pregnant women attending antenatal care," Journal of Health, Medicine and Nursing, vol. 50, pp. 31-40, 2018.

[3] D. S. Silverberg, Anemia, InTechOpen, Croatia, 2012.

[4] M. S. Nurdin, V. Hadju, A. Ansariadi, A. Zulkifli, and A. I. Arundhana, "Determinants of anemia among pregnant women in jeneponto regency," Asian Pacific Journal of Health Sciences, vol. 5, no. 1, pp. 135-138, 2018.

[5] B. Ayano and B. Amentie, "Assessment of prevalence and risk factors for anemia among pregnant mothers attending ANC clinic at Adama hospital medical collage, Adama, Ethiopia, 2017," Journal of Gynecology and Obstetrics, vol. 6, no. 3, pp. 31-39, 2018.

[6] R. I. Kemenkes, Hasil Utama Laporan Riskesdas, Kementerian Kesehatan Republik Indonesia, Jakarta, Indonesia, 2018.

[7] G. Stephen, M. Mgongo, T. Hussein Hashim, J. Katanga, B. Stray-Pedersen, and S. E. Msuya, "Anaemia in pregnancy: prevalence, risk factors, and adverse perinatal outcomes in northern Tanzania," Anemia, vol. 2018, Article ID 1846280, 9 pages, 2018

[8] F. Iradukunda, "Food taboos during pregnancy," Health Care for Women International, vol. 41, no. 2, pp. 159-168, 2020.

[9] M. Skreden, E. Bere, L. R. Sagedal, I. Vistad, and N. C. Øverby, "Changes in beverage consumption from pre-pregnancy to early pregnancy in the norwegian fit for delivery study," Public Health Nutrition, vol. 18, no. 7, pp. 1187-1196, 2015.

[10] J. Juariah, "Kepercayaan dan praktik budaya pada masa kehamilan masyarakat desa karangsari, kabupaten garut," Sosiohumaniora: Journal of Social Sciences and Humanities, vol. 20, no. 2, pp. 162-167, 2018.

[11] S. Daud, Adat Meukawen (Adat Perkawinan Aceh), p. 218, Majelis Adat Aceh, Banda Aceh, Indonesia, 2014.

[12] B. Ismail, R. Sufi, M. D. Joesoef, and H. K. Leumiek, Nurdin: Ensiklopedia Budaya Adat Aceh, Majelis Adat Aceh, Banda Aceh, Indonesia, 2018.

[13] M. Hoesin, Islam Dan Adat Aceh, Aceh Besar: Lembaga Studi Kebudayaan dan Pembangunan Masyarakat, Jantho City, Indonesia, 2018.

[14] M. Vaismoradi, J. Jones, H. Turunen, and S. Snelgrove, "Theme development in qualitative content analysis and thematic analysis," Journal of Nursing Education and Practice, vol. 6, no. 5, pp. 100-110, 2016.

[15] N. J. Kassebaum, R. Jasrasaria, M. Naghavi et al., "A systematic analysis of global anemia burden from 1990 to 2010," Blood, vol. 123, pp. 615-625, 2015.

[16] M. Sumitra and C. T. Kumari, "Determinants of anemia among pregnant women attending in a tertiary level hospital, Kathmandu," Med Phoenix, vol. 2, no. 1, pp. 24-33, 2017.

[17] N. Abu-Ouf and M. Jan, "The impact of maternal iron deficiency and iron deficiency anemia on child's health," Saudi Medical Journal, vol. 36, no. 2, pp. 146-149, 2015.

[18] N. Chatterjee and G. Fernandes, "This is normal during pregnancy': a qualitative study of anaemia-related perceptions and practices among pregnant women in Mumbai, India," Midwifery, vol. 30, no. 3, pp. e56-e63, 2014.

[19] J. Lennox, P. Petrucka, and S. Bassendowski, "Eating practices during pregnancy: perceptions of select Maasai women in Northern Tanzania," Global Health Research and Policy, vol. 2, no. 1, p. 9, 2017.

[20] F. Zakaria, M. W. Aisya, and Y. Lamatowa, "Effectiveness of mung bean drink on the improvement of hemoglobin in female adolescents in Paguyaman district," Saudi Journal of Biomedical Research (SJBR), vol. 3, pp. 125-128, 2018.

[21] R. I. Kemenkes, Pedoman Pelayanan Antenatal Terpadu. Jakarta: Kementerian Kesehatan Republik Indonesia, Direktur Jenderal Bina Kesehatan Masyarakat, Jakarta, Indonesia, 2010.

[22] M. Y. Yakoob and Z. A. Bhutta, "Effect of routine iron supplementation with or without folic acid on anemia during pregnancy," BMC Public Health, vol. 11, no. 3, p. S21, 2011.

[23] H. Barton, Yams: Origins and Development. Encyclopedia of Global Archaeology, pp. 7943-7947, Springer, New York, NY, USA, 2014.

[24] D. Noujaim, R. H. Fortinsky, and L. C. Barry, "The relationship between emotional support and health-related selfefficacy in older prisoners," Journal of Aging and Health, vol. 31, no. 3, pp. 439-462, 2017.

[25] Aditiawarman, N. K. A. Armini, and Y. I. Kristanti, "Manfaat dukungan sosial keluarga pada perilaku antisipasi tanda bahaya kehamilan pada ibu primigravida," Ners Journal, vol. 3, 2017.

[26] P. Dako-Gyeke, M. Aikins, R. Aryeetey, L. Mccough, and P. B. Adongo, "The influence of socio-cultural interpretations of pregnancy threats on health-seeking behavior among pregnant women in urban Accra, Ghana," BMC Pregnancy and Childbirth, vol. 13, no. 1, 2013. 